\title{
FAKTOR PENGARUH KEBETAHAN DAN KEBAHAGIAAN PADA RUANG YANG SERING DIGUNAKAN DI RUMAH
}

\author{
Lukman Hendra Septian; Feni Kurniati; Angela C Tampubolon \\ Institut Teknologi Bandung \\ Jl. Ganesha 10 Bandung 40132 Jawa Barat, Indonesia \\ lukmanhendras@gmail.com
}

\begin{abstract}
Abstrak
Rumah tinggal mewadahi aktivitas keluarga dan individu, serta dapat menjadi sumber kebetahan dan kebahagiaan. Penelitian ini mencoba untuk mencari tahu korelasi antara karakteristik tempat dan kegiatan pada kebetahan dan kebahagiaan di rumah tinggal. Penelitian ini menggunakan metode campuran kualitatif dan kuantitatif. Data dikumpulkan dengan survey menggunakan kuesioner online. Data teks penelitian kualitatif dianalisis dengan analisis isi. Data numerik penelitian kuantitatif dianalisis dengan analisis faktor, analisis korelasi, dan analisis regresi. Dari hasil penelitian ini terungkap kecenderungan dimensi Ketenangan dan Suasana Hidup dapat meningkatkan kebetahan dan kebahagiaan. Dimensi Keberadaan Orang lain cenderung mengurangi kebetahan, tetapi meningkatkan kebahagiaan. Dimensi kegiatan Hiburan dapat meningkatkan kebetahan, tetapi tidak mempengaruhi kebahagiaan. Keterlibatan dengan orang lain cenderung dapat meningkatkan kebahagiaan seseorang. Tetapi, belum tentu berpengaruh terhadap kebetahan.
\end{abstract}

Kata kunci: karakteristik tempat, kebahagiaan, kebetahan, kegiatan, respon afektif/kognitif.

\section{Pendahuluan}

Rumah merupakan kebutuhan pokok manusia selain sandang dan pangan. Yatmo \& Paramita (2013) menegaskan bahwa bukan sesuatu yang mudah untuk memahami makna 'rumah' bagi orang Indonesia, hal tersebut diuraikan bukan saja rumah sebagai 'ruang tinggal', tetapi juga memaknai rumah dengan fungsi kegiatan tertentu (contoh: rumah baca), rumah dengan arti kiasan (rumah sakit), rumah yang ditingali pada waktu tertentu (rumah dinas), rumah adat (rumah Panjang), penamaan rumah dengan material (rumah kaca), gubuk, rumah dengan makna negatif dalam konteks tertentu yaitu rumah sebagai tempat penyingkiran (di'rumah'kan). Rumahrumah yang berkelompok yang turut menjadi bagian dari dinamika proses pertumbuhan kota juga turut menambah terminologi pemaknaan terhadap rumah, serta 'rumah tua' juga merupakan bagian pemaknaan terhadap rumah. Rumah menurut Budiharjo (dalam Luthfiah, 2010) mempunyai beberapa fungsi: (1) simbol dan pencerminan tata nilai dan selera penghuninya; (2) wadah keakraban, rasa memiliki, kebersamaan, kehangatan, kasih dan rasa aman; (3) tempat menyendiri dan menyepi. Tempat untuk melepaskan diri dari dunia luar, dari tekanan dan ketegangan rutinitas; (4) Rumah sebagai pusat jaringan sosial serta struktur fisik. Rumah telah menjadi bagian keseharian kita, sampai pemberian nama 'rumah-' terhadap tempat-tempat yang dipakai manusia untuk beraktivitas sangat beragam sesuai konteks maupun fungsinya. Dalam keseharian, rumah tinggal menjadi tempat yang paling dominan sebagai wadah manusia dalam berbagai kegiatan yang bersifat individu maupun publik.

Dalam teori Maslow tentang hirarki kebutuhan, rumah berfungsi sebagai wadah kegiatan penghuni; melindungi penghuni dan menciptakan rasa aman; tempat interaksi sosial antara anggota keluarga dan orang lain; tempat akumulasi 
pengalaman dan memori; serta simbol keberadaan dan identitas penghuni (Maslow dalam Apriliyadi, 2015). Rumah, penghuni, dan kegiatan didalamnya juga dapat menumbuhkan kebetahan maupun kebahagiaan bagi penghuninya.

Kebetahan termasuk suatu bentuk respon manusia setelah berinteraksi dengan lingkungan. Respon tersebut dapat berupa respon afektif, kognitif, dan perilaku yang terjadi saat berada pada suatu tempat. Rachman \& Kusuma (2016) mendefinisikan kebetahan menjadi beberapa pengertian: (1) Keadaan nyaman dan senang sehingga ingin berlama-lama tinggal di suatu tempat; (2) Kondisi manusia merasa tenang, santai, dan bebas tanpa beban sehingga tahan berada di suatu tempat; (3) Kondisi kebutuhan manusia terpenuhi saat berada di suatu tempat dan adanya ikatan psikologis terhadap tempat; (4) Kondisi psikologis manusia merasa nyaman dan puas sehingga senang untuk berlama-lama di suatu tempat.

\section{Kebetahan pada rumah tinggal diwujudkan dengan suasana ruang keluarga yang ideal (Kusyanto, 2016). Ruang keluarga tersebut dimaknai sebagai tempat seluruh keluarga sering berkumpul melakukan aktivitas bersama. Suasana ruang keluarga yang ideal meliputi luas ruangan, suasana ruang, interaksi keluarga dan kenyamanan, adanya hiburan. Dapat disimpulkan bahwa kebetahan dapat diwujudkan dari aspek fisik ruangan yang digunakan (luas ruangan, kenyamanan) serta aspek non-fisik (suasana ruang, interaksi dengan keluarga, dan adanya hiburan).}

Kebahagiaan merupakan harapan dan cita-cita terbesar bagi setiap individu dari berbagai latar belakang, baik usia, tempat tinggal, status sosial, maupun agama (Ardyansyah, 2014). Veenhoven (dalam Ardyansyah, 2014) menegaskan bahwa kebahagiaan merupakan konsep yang subjektif yang sering dialami oleh setiap individu dari waktu ke waktu sebagai gambaran perasaan atau emosi. Sehingga, hanya individu yang mengetahui apakah mereka bahagia atau tidak dalam kehidupan yang mereka jalani.

Kebahagiaan setiap individu muncul dengan cara yang beragam sesuai dengan kepribadian dan lingkungan yang dapat mempengaruhinya. Dipertegas Khavari (dalam Putra \& Nashori, 2008) bahwa kebahagiaan bergantung pada empat aspek, yaitu material, intelektual, emosional, dan spiritual. Selain itu kebahagiaan juga dapat menghasilkan manfaat positif untuk masyarakat. Hal ini diperjelas dengan pernyataan Lyubomirsky (dalam Na'imah, Nur'aeni, \& Septiningsih, 2017) bahwa kebahagiaan berkaitan secara positif dengan perilaku dan atribut positif seseorang, seperti sosialisasi, kreativitas, dan persepsi positif terhadap diri sendiri dan orang lain. Dari pernyataan diatas, dapat disimpulkan bahwa kebahagiaan merupakan perasaan positif seseorang sebagai respon terhadap lingkungan yang dapat memberikan dampak positif kehidupan masyarakat.

Merujuk pada paragraf di atas, rumah tinggal mengindikasikan punya peran yang signifikan dalam mewujudkan kebahagiaan seseorang. Rumah tinggal merupakan sumber kebahagiaan yang umum bagi setiap orang. Tetapi tidak menutup kemungkinan memang ada juga sebagian orang yang dapat merasakan kebahagiaan selain di rumah, misalnya berkunjung ke tempat wisata atau bahkan berkunjung ke tempat perbelanjaan.

Dalam berhuni, setiap orang selalu berusaha untuk meningkatkan kebetahan dan kebahagiaan. Berbagai cara dapat dilakukan untuk meningkatkan hal tersebut melalui aspek fisik (ukuran ruang, warna ruang, atau bentuk ruang) dan aspek sosial. Sehingga menarik untuk diteliti hubungan antara kebetahan dan kebahagiaan dengan rumah tinggal. Penelitian ini mencoba untuk mencari tahu apa pengaruh karakteristik tempat dan kegiatan pada kebahagiaan dan kebetahan di rumah tinggal. Harapannya, penelitian ini bisa menjadi bahan pembelajaran dalam memahami bagaimana hubungan rumah tinggal dengan kebetahan dan kebahagiaan. 


\section{Metode}

Penelitian ini adalah penelitian dengan metode campuran kualitatif dan kuantitatif (Creswell, 2012). Exploratory research (Kumar, 2005) digunakan untuk mengetahui faktor atau variabel-variabel mengenai ruang yang sering digunakan penghuni, bentuk kegiatan yang dilakukan, karakteristik ruang, dan tingkat kebahagiaan dan kebetahan (kualitatif). Correlational research (Kumar, 2005) digunakan untuk mencari tahu keterkaitan antara hubungan tersebut (kuantitatif).

Pengumpulan data terdiri dari dua data yaitu data primer dan sekunder. Data primer dilakukan dengan cara survey online melalui Google Form yang disebar secara acak dari berbagai latar belakang pekerjaan, asal tempat tinggal, dan variasi tipe rumah tinggal yang dihuni, sedangkan data sekunder terdiri dari data-data yang bersifat teori yang didapat dari jurnal dan buku yang terkait dengan hunian dan behavioral setting. Penelitian ini menggunakan nonprobability sampling, sehingga hasil yang didapat hanya menggambarkan kesimpulan dari kelompok responden (Creswell, 2012).

Penelitian ini dilakukan melalui dua tahap pengumpulan data. Tahap pertama dilakukan pengumpulan data online openended questionaire. Responden diminta untuk menyebutkan ruang mana di rumah tinggal yang mereka sering gunakan sehari hari, aktivitas yang dilakukan, alasan memilih ruang tersebut. Pengumpulan data dilakukan mulai dari tanggal 28 September 2017 sampai 2 Oktober 2017 dengan 93 responden.

Hasil dari analisis konten kuesioner di tahap pertama yang didasarkan pada ruang yang sering digunakan, aktivitas yang dilakukan, dan alasan menggunakan ruang tersebut bahwa ruang yang paling sering digunakan: "ruang tv", "ruang tamu", "ruang keluarga", "ruang makan", "ruang serbaguna", "ruang tengah", "ruang santai", "ruang belajar", "kamar tidur". Sedangkan aktivitas yang dilakukan adalah "istirahat", "tidur", "shalat", "makan", "bekerja", "belajar", "mencari inspirasi", "berkumpul dengan keluarga", "nonton tv", "bermain", "ngobrol bersama", dan "duduk santai". Sedangkan alasan memilih ruang tersebut dipengaruhi oleh faktor karakteristik ruang dan aspek kognitif/afektif dari penghuni.

Hasil analisis konten dari kuesioner di tahap pertama digunakan untuk menyusun kuesioner tertutup untuk menghasilkan data numerik berskala 1 - 5 (lihat Tabel 1) yang disebut sebagai semantic differential (SD Method). Kuesiner di tahap ke dua dikelompokkan menjadi ruang yang paling sering digunakan, aktivitas apa yang dilakukan, aspek kognitif - afektif yang mempengaruhi pemilihan ruang tersebut dan karakteristik ruang tersebut dan juga kebetahan - kebahagiaan. Kuesioner online disebar mulai tanggal 19 Oktober 2017 sampai 30 Oktober 2017 dengan jumlah 115 responden.

Tabel 1: Contoh pertanyaan menggunakan SD Method

Kategori Contoh Pertanyaan

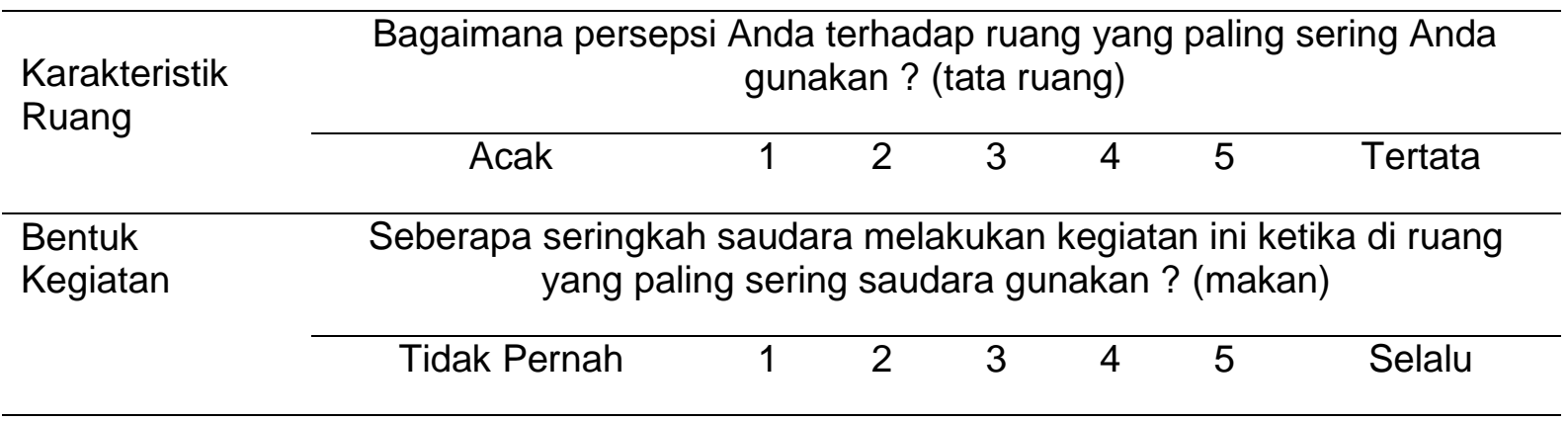


Setelah data terkumpul lebih dari 100 responden, dilakukan analisis data kuantitatif dengan menggunakan principal component analysis (PCA), multivariate correlation analysis, dan analisis regresi. PCA digunakan untuk mengidentifikasi variabel baru dari beberapa variabel yang beragam yang disebut dengan pincipal components.

\section{Kajian Teori}

\section{Kebahagiaan}

Salah satu hal yang paling dicari-cari manusia di lingkungan adalah "kebahagiaan". Menurut Saligman (dalam Ardiansyah, 2014), kebahagiaan didefinisikan sebagai konsep yang mengacu pada emosi dan kegiatan positif yang dirasakan individu. Diperjelas dengan Spot (dalam Putra \& Nashori, 2008) yang mendefinisikan kebahagiaan sebagai penghayatan dari perasaan emosional yang positif karena terpenuhinya segala kebutuhan, lepas dari segala sesuatu yang menyusahkan, serta tercapainya suatu tujuan, atau kondisi dimana seseorang merasa senang dan puas secara keseluruhan terhadap kehidupan yang dijalaninya.

Kebahagiaan hanya didapat dengan lebih banyak aspek kegiatan positif dibandingkan dengan negatif setiap individu. Seligman (dalam Impisari , 2017) mengungkapkan sumber kebahagiaan sejati di antaranya terjalinnya hubungan positif dengan orang lain, keterlibatan penuh, penemuan makna hidup, optimisme yang realistis, dan kemampuan untuk bangkit dari peristiwa yang tidak menyenangkan. Kebahagiaan dapat diperoleh melalui berbagai cara dan berbagai pemaknaan yang dipengaruhi oleh masing-masing individu, lingkungan, dan kondisi tertentu.

Kebahagiaan merupakan konsep yang subjektif tergantung dari faktor-faktor yang berpengaruh terhadap setiap individu. Menurut Seligman (dalam Ardiansyah, 2014) terdapat dua faktor yang mempengaruhi kebahagiaan setiap orang, di antaranya faktor internal, yaitu kepuasan terhadap masa lalu dan optimisme terhadap masa depan. Sedangkan faktor eksternal yang mempengaruhi kebahagiaan seseorang adalah uang, status pernikahan, kehidupan sosial, usia, kesehatan, pendidikan, iklim, ras, jenis kelamin, agama atau tingkat religiusitas setiap individu.

Khavari (dalam Putra \& Nashori, 2008) berpandangan bahwa kebahagiaan bergantung pada empat aspek, yaitu material, intelektual, emosional, dan spiritual. Putra \& Nashori (2008) dalam penelitiannya "kebahagiaan pada penyandang cacat tubuh bahwa faktorfaktor yang mempengaruhi kebahagiaan pada penyandang cacat tubuh" adalah pergaulan sosial, cinta dan perkawinan, kepuasan kerja, dan religiusitas (agama). Hal ini dapat dilihat bahwa terdapat faktor internal dan eksternal yang berpengaruh terhadap kebahagiaan seseorang.

Peterson dan Seligman (dalam Na'imah, Nur'aeni, \& Septiningsih, 2017) menyatakan bahwa ada tiga elemen orientasi kebahagiaan yaitu emosi positif, engagement, dan kebermaknaan. Orientasi kebahagiaan seseorang dengan emosi positif akan lebih fokus pada pencapaian kesenangan dan cenderung menghindari hal-hal yang berpotensi menimbulkan penderitaan. Tetapi orientasi pada elemen engagement cenderung diperoleh melalui sebuah rangkaian proses aktivitas dengan keterlibatan diri seseorang sesuai dengan minatnya.

\section{Kebetahan}

Kondisi dari hasil interaksi antara manusia dengan lingkungannya dapat diartikan sebagai kebetahan. Konteks tempat dan ruang akan selalu berkaitan dengan kebetahan yang dapat menyebabkan seseorang merasa terikat secara emosional dan kultural. Istilah "kebetahan" dapat digunakan untuk mengkaji respon manusia terhadap tempat.

Purwanti (dalam Rachman \& Kusuma, 2014) mendefinisikan kebetahan (pada rumah susun) sebagai pencerminan dari kondisi psikologis penghuni, karena sudah 
merasa senang di suatu tempat yang dicerminkan melalui lama tinggal, rencana penghunian, dan kepuasan penghunian. Sedangkan Rachman \& Kusuma (2016) mendefinisikan kebetahan menjadi beberapa pengertian: (1) keadaan nyaman dan senang sehingga ingin berlama-lama tinggal di suatu tempat; (2) kondisi manusia merasa tenang, santai, dan bebas tanpa beban sehingga tahan berada di suatu tempat; (3) kondisi dimana kebutuhan manusia terpenuhi saat di suatu tempat dan adanya ikatan psikologis terhadap tempat; (4) kondisi psikologis dimana manusia merasa nyaman dan puas sehingga senang untuk berlama - lama di suatu tempat. Penelitian tersebut membagi kriteria kebetahan menjadi dua aspek, Fisik: (1) kelengkapan fasilitas; dan (2) desain yang menarik. Sedangkan aspek Sosial adalah tidak adanya interaksi sosial di ruang tersebut.

\section{Hasil Penelitian Dan Pembahasan}

Hasil analisis dan pembahasan dibagi ke dalam empat bagian. Yang pertama hasil analisis dan pembahasan tentang karakteristik tempat, dilanjutkan dengan hasil analisis dan pembahasan tentang respon afektif-kognitif, kegiatan, kebetahan-kebahagiaan dan yang terakhir hasil analisis dan pembahasan tentang hubungan korelasional antara karakteristik tempat, respon afektif-kognitif, kegiatan dan kebetahan-kebahagiaan.

\section{Karakteristik Tempat}

Kelompok variabel karakteristik tempat terdiri dari atas 14 variabel terukur. Dari hasil analisis faktor diperoleh 4 dimensi yang mewakili 14 variabel terukur tersebut, yaitu "Kenyamanan", "Keberadaan Orang", "Fleksibilitas" dan "Fasilitas". Kenyamanan mewakili variabel terukur "suara", "Iuasan ruangan", "sirkulasi udara", "kebersihan", "bau", "tata-ruang" dan "suhu udara". Semua variabel terukur yang diwakili oleh kenyamanan merupakan kualitas fisik yang dapat dirasakan secara langsung secara visual, audial, ataupun motorik. Dimensi yang ke-dua yaitu Keberadaan Orang, dimensi ini mewakili variabel terukur "keberadaan orang", "pencahayaan ruang", dan "privasi". Meskipun di dalamnya terdapat variabel terukur pencahayaan ruang, dimensi yang ke-dua ini cenderung merepresentasikan kualitas sosial dari tempat. Dimensi yang ke-tiga dan keempat, Fleksibilitas dan Fasilitas, mewakili variabel terukur "dapat digunakan untuk aktivitas lain", "tekstur pelingkup ruangan", "hiburan", dan "makanan". Dua dimensi tersebut cenderung menrepresentasikan fungsi dari ruang. Dari hasil analisis faktor kelompok variabel karakteristik tempat, terungkap empat dimensi yang mewakili kualitas fisik, kualitas sosial, dan fungsi dari tempat.

\section{Tabel 2: Variabel laten dari faktor analisis dengan varimax rotation dari empat prinsip komponen}

\begin{tabular}{lcccc}
\hline \multicolumn{1}{c}{ Variabel } & Kenyamanan & $\begin{array}{c}\text { Keberadaan } \\
\text { Orang }\end{array}$ & Fleksibilitas & Fasilitas \\
\hline Suara & $\mathbf{0 , 7 3}$ & $-0,20$ & 0,04 & 0,05 \\
\hline Luasan Ruangan & $\mathbf{0 , 6 9}$ & 0,23 & 0,07 & 0,30 \\
\hline Sirkulasi Udara & $\mathbf{0 , 6 2}$ & 0,43 & 0,35 & 0,07 \\
\hline Kebersihan & $\mathbf{0 , 6 2}$ & 0,10 & 0,48 & 0,05 \\
\hline Bau & $\mathbf{0 , 6 0}$ & $-0,07$ & 0,28 & 0,48 \\
\hline Tata Ruang & $\mathbf{0 , 5 4}$ & $-0,07$ & 0,61 & $-0,16$ \\
\hline
\end{tabular}




\begin{tabular}{lcccc}
\hline Suhu Udara & $\mathbf{0 , 4 7}$ & $-0,47$ & 0,02 & 0,16 \\
\hline Keberadaan Orang & 0,08 & $\mathbf{0 , 7 7}$ & $-0,03$ & 0,22 \\
\hline Pencahayaan Ruang & 0,40 & $\mathbf{0 , 5 0}$ & 0,37 & 0,22 \\
\hline Privasi & 0,07 & $\mathbf{- 0 , 7 7}$ & 0,09 & 0,08 \\
\hline $\begin{array}{l}\text { Dapat Digunakan } \\
\text { Untuk Aktivitas Lain }\end{array}$ & $-0,05$ & 0,13 & $\mathbf{0 , 8 4}$ & 0,28 \\
\hline $\begin{array}{l}\text { Tekstur Pelingkup } \\
\text { Ruangan }\end{array}$ & 0,26 & $-0,19$ & $\mathbf{0 , 6 8}$ & 0,07 \\
\hline $\begin{array}{l}\text { Hiburan (Tv, Radio, } \\
\text { Komputer, DII) }\end{array}$ & 0,16 & $-0,08$ & 0,05 & $\mathbf{0 , 8 1}$ \\
\hline Makanan & 0,09 & 0,42 & 0,18 & $\mathbf{0 , 7 1}$ \\
\hline
\end{tabular}

\section{Afektif-Kognitif}

Tabel 3 mendeskripsikan kelompok variabel afektif-kognitif yang terdiri dari lima variabel terukur. Hasil dari analisis faktor diperoleh dua dimensi yang mewakili variabel-variabel terukur tersebut, yaitu "Ketenangan" dan "Suasana hidup". Dimensi yang pertama yaitu Ketenangan mewakili variabel terukur "tenang", "fokus", "nyaman", dan "rileks". Sedangkan dimensi yang kedua "Suasana hidup" yang mewakili variabel tunggal "Suasana hidup", walaupun hanya satu variabel terukur tetapi memiliki nilai yang tinggi $(0,91)$ sehingga penamaan mengikuti variabel terukur "suasana hidup".

Tabel 3: Variabel laten dari factor analisis dengan dua prinsip komponen varimax rotation

\begin{tabular}{lrr}
\hline \multicolumn{1}{c}{ Variabel } & Ketenangan & $\begin{array}{l}\text { Suasana } \\
\text { Hidup }\end{array}$ \\
\hline Tenang & $\mathbf{0 , 8 5}$ & $-0,03$ \\
\hline Fokus & $\mathbf{0 , 8 0}$ & 0,06 \\
\hline Nyaman & $\mathbf{0 , 7 0}$ & 0,49 \\
\hline Rileks & $\mathbf{0 , 5 9}$ & 0,52 \\
\hline Suasana Hidup & $-0,02$ & $\mathbf{0 , 9 1}$ \\
\hline
\end{tabular}

\section{Kegiatan di Rumah}

Hasil dari analisis faktor mengenai kegiatan yang sering dilakukan di dalam rumah, terdapat empat dimensi yang memiliki eigenvalue lebih dari satu. Sehingga keempat dimensi ini digunakan sebagai variabel laten yang merepresentasikan sebelas variabel terukur. Tabel 4 mendeskripsikan empat dimensi yang didapat dari analisis faktor. Keempat dimensi tersebut dinamai "Makan dan Interaksi", Belajar dan Bekerja", "Istirahat", dan "Hiburan". Dimensi yang pertama Makan dan Interaksi mewakili variabel terukur "makan", "duduk santai", 
dan "bincang-bincang". Dimensi berikutnya "Belajar dan Bekerja" mewakili variabel terukur "belajar", "kerja", dan "ibadah". Dimensi ketiga "Istirahat" yang mewakili variabel terukur "istirahat" dan "tidur". Dimensi yang terakhir yaitu "Hiburan" yang mewakili variabel terukur "Nonton televisi", "Bermain", dan "Kumpul keluarga". Semua variabel terukur yang diwakili dimensi "makan dan interaksi", "belajar dan bekerja", dan "hiburan" cenderung merepresentasikan kegiatan yang melibatkan lebih dari satu orang / kelompok. Sedangkan dimensi yang ketiga, istirahat merepresentasikan kegiatan yang bersifatnya sendiri. Empat dimensi hasil analisis faktor mewakili kegiatan yang melibatkan lebih dari satu orang dan kegiatan yang dilakukan hanya satu orang.

\section{Tabel 4: Variabel laten dari analisis faktor denganvarimax rotation dari empat prinsip komponen}

\begin{tabular}{lcccc}
\hline \multicolumn{1}{c}{ Variabel } & $\begin{array}{c}\text { Makan } \\
\text { dan } \\
\text { Interaksi }\end{array}$ & $\begin{array}{c}\text { Belajar } \\
\text { dan } \\
\text { Bekerja }\end{array}$ & Istirahat & Hiburan \\
\hline Makan & $\mathbf{0 , 7 8}$ & 0,10 & 0,17 & 0,04 \\
\hline Duduk santai & $\mathbf{0 , 7 7}$ & 0,17 & 0,03 & 0,26 \\
\hline $\begin{array}{l}\text { Bincang - } \\
\text { bincang }\end{array}$ & $\mathbf{0 , 7 6}$ & $-0,07$ & $-0,15$ & 0,21 \\
\hline Belajar & 0,04 & $\mathbf{0 , 8 7}$ & 0,21 & $-0,04$ \\
\hline Kerja & 0,17 & $\mathbf{0 , 8 4}$ & 0,12 & $-0,03$ \\
\hline Ibadah & $-0,18$ & $\mathbf{0 , 6 1}$ & 0,48 & $-0,18$ \\
\hline Istirahat & 0,15 & 0,13 & $\mathbf{0 , 8 8}$ & 0,05 \\
\hline Tidur & $-0,11$ & 0,29 & $\mathbf{0 , 8 7}$ & $-0,02$ \\
\hline Nonton televisi & 0,11 & $-0,26$ & 0,03 & $\mathbf{0 , 8 5}$ \\
\hline Bermain & 0,35 & 0,23 & 0,03 & $\mathbf{0 , 7 5}$ \\
\hline Kumpul & 0,48 & $-0,26$ & $-0,22$ & $\mathbf{0 , 4 9}$ \\
\hline keluarga & & & & \\
\hline
\end{tabular}

Bagi keluarga "rumah" berfungsi sebagai tempat berkumpul sebuah keluarga (Epifania, 2013). Rumah sebagai pusat ruang sosial mempunyai peran penting dalam hubungan keluarga. Menurut Safino (dalam Ardiansyah, 2014) dukungan sosial adalah tindakan yang mengacu pada pemberian kenyamanan pada orang lain, merawatnya atau menghargainya. Diener (dalam Ardiansyah, 2014) mengatakan bahwa salah satu sumber terpenting kebahagiaan adalah adanya hubungan pribadi yaitu persahabatan, pernikahan, keintiman, dan dukungan sosial. Dukungan sosial tersebut diperoleh dari keluarga, teman, masyarakat atau organisasi.

Orientasi kebahagiaan dapat mempengaruhi tindakan dan pilihan aktivitas yang dilakukan individu (Peterson \& Seligman dalam Na'imah, Nur'aeni, \& 
Septiningsih, 2017). Rumah mampu memberikan kenyamanan melalui dukungan sosial melalui kegiatan yang dilakukan bersama maupun individu. Dari hasil analisis, dapat dilihat bahwa dimensi Makan dan Interaksi merupakan dimensi yang pertama, dimensi yang paling dominan merepresentasikan karakteristik tempat, dan mengindikasikan kegiatan yang umum dilakukan untuk mendapatkan dukungan sosial dari keluarga. Dimensi makan dan interaksi cenderung bersifat sosial jika dibandingkan tiga dimensi yang lain (belajar dan bekerja, istirahat, dan hiburan).

\section{Kebetahan dan Kebahagiaan}

Hasil dari analisis faktor "kebetahan-kebahagiaan" menghasilkan dua dimensi: (1) kebetahan, mewakili variabel terukur "betah terhadap ruang yang sering digunakan", "bahagia terhadap ruang yang sering digunakan", dan "puas terhadap ruang yang sering digunakan". Kebetahan merupakan interaksi yang terjadi karena adanya pengamat dan kondisi lingkungan itu sendiri. Diperjelas dengan pernyataan Indra (dalam Rachman \& Kusuma, 2016) dalam melakukan evaluasi paska-huni pada rumah susun sederhana Kota Bandar Baru Kemayoran bahwa kebetahan sebagai perasaan senang manusia yang menghuni suatu tempat, lama tinggal, dan tidak adanya keinginan untuk pindah. Dapat diinterpretasikan bahwa kebetahan mengandung unsur waktu dan kualitas tempat.

Dimensi yang kedua yaitu "kebahagiaan". Dimensi ini mewakili variabel terukur "kebahagiaan saat ini". Seligman (dalam Lewi \& Sudarji, 2015) kebahagiaan saat ini pada seseorang melibatkan dua hal. Pertama yaitu kesenangan yang memiliki komponen indrawi dan emosional yang kuat, perasaan-perasaan dasar seperti gairah, rasa senang dan nyaman yang diartikan sebagai kesenangan. Yang kedua adalah kegiatan yang sangat disukai oleh seseorang namun tidak selalu melibatkan perasaan tertentu dan durasinya lebih lama dibandingkan pleasure yang disebut sebagai gratifikasi. Kebahagiaan juga dipengaruhi oleh beberapa aspek, antara lain terjalinnya hubungan yang positif dengan orang lain, keterlibatan penuh, penemuan makna dalam keseharian, optimisme yang realistis, dan resiliensi (Seligman, 2005).

\section{Tabel 5: Variabel laten dari analisis faktor dengan varimax rotation dari dua prinsip komponen}

\begin{tabular}{lrr}
\hline \multicolumn{1}{c}{ Variabel } & Kebetahan & Kebahagiaan \\
\hline $\begin{array}{l}\text { Betah terhadap ruang yang sering } \\
\text { digunakan }\end{array}$ & 0,90 & 0,27 \\
\hline $\begin{array}{l}\text { Bahagia terhadap ruang yang sering } \\
\text { digunakan }\end{array}$ & 0,84 & 0,42 \\
\hline $\begin{array}{l}\text { Puas terhadap ruang yang sering } \\
\text { digunakan }\end{array}$ & 0,78 & 0,45 \\
\hline Kebahagiaan saat ini & 0,37 & 0,92 \\
\hline
\end{tabular}

\section{Hubungan antar Dimensi}

Analisis regresi digunakan untuk melihat seberapa besar pengaruh dimensidimensi karakteristik tempat, afektif/kognitif, dan kegiatan terhadap kebetahan dan kebahagiaan. Hasil analisis regresi dapat dilihat pada tabel 6 . Kebetahan cenderung lebih besar 
dipengaruhi oleh faktor internal. Sedangkan kebahagiaan cenderung dipengaruhi oleh faktor eksternal.

Nilai dimensi terbesar yang mempengaruhi kebetahan adalah "ketenangan" $(r=0,36)$, kemudian "hiburan" $(r=0,24)$, "keberadaan orang" $(r=-0,21)$, "suasana hidup" $(r=0,20)$, serta "makan dan interaksi" $(r=0,18)$. Walaupun dimensi keberadaan orang lain mempunyai nilai- $r$ tinggi $(r=-0,21)$. Tetapi, nilai negatif mempunyai arti yang sebaliknya. Artinya, kebetahan pada seseorang tidak dapat terwujud jika ruang yang digunakan terdapat banyak orang. Temuan ini diperkuat juga dengan penelitian yang dilakukan oleh Satriaji (2017) bahwa kebetahan mahasiswa terhadap sebuah ruang/lingkungan dalam kampus dapat disebabkan oleh tiga kriteria, yaitu interaksi dengan pengguna lain (sosial), ruang dan fasilitas (fisik) serta aktivitas yang dilakukan di dalam kampus. Unsur kegiatan manusia mengandung empat hal yaitu: pelaku, bentuk kegiatan, tempat dan waktu berlangsungnya kegiatan (Rapoport dalam Luthfiah, 2010). Sebelumnya, Rachman dan Kusuma (2014) mendefinisikan kebetahan sebagai kondisi psikologis dimana manusia merasa nyaman dan puas sehingga senang untuk berlama-lama melakukan kegiatan-kegiatan yang disukainya pada suatu tempat. Sehingga, kebetahan dapat terwujud jika seseorang merasa tenang dalam waktu yang tidak singkat dalam melakukan kegiatan di sebuah ruangan dengan tidak banyak orang. Misalnya, seseorang melakukan kegiatan seperti hiburan serta makan dan interaksi yang dapat menghidupkan suasana.

Kebahagiaan cenderung memiliki korelasi yang tinggi terhadap "suasana hidup" $(r=0,34)$, "ketenangan" $(r=0,32)$, dan "keberadaan orang" $(r=0,23)$. Kebahagiaan cenderung dapat dicapai melalui interaksi dengan orang lain. Manusia merupakan makhluk sosial yang memiliki kebutuhan dan kemampuan untuk hidup berkelompok serta berkomunikasi dengan orang lain (Lestari, 2013). Aristoteles menyatakan (dalam Lestari, 2013) bahwa manusia sebagai zoon politicon, yang artinya manusia memiliki kemampuan untuk hidup berkelompok hidup dengan manusia lainnya dalam satu organisasi yang memiliki tujuan yang jelas. Tujuan manusia hidup berkelompok adalah untuk meningkatkan kebahagiaan dan kesejahteraan. Suasana hidup, ketenangan, dan keberadaan orang lain merupakan faktor yang didominasi oleh keterkaitan dengan orang lain sehingga dapat meningkatkan kebahagiaan.

Tabel 6: Analisis regresi

\begin{tabular}{lccrr}
\hline & \multicolumn{2}{c}{ Kebetahan } & \multicolumn{2}{c}{ Kebahagiaan } \\
\cline { 2 - 5 } & $\begin{array}{c}\text { Bobot } \\
\text { Regresi }\end{array}$ & Sig.Value & $\begin{array}{c}\text { Bobot } \\
\text { Regresi }\end{array}$ & Sig.Value \\
\hline Kenyamanan & 0,08 & 0,42 & $-0,04$ & 0,77 \\
\hline $\begin{array}{l}\text { Keberadaan } \\
\text { Orang }\end{array}$ & $-0,21$ & 0,05 & 0,23 & 0,08 \\
\hline Fleksibilitas & 0,10 & 0,27 & $-0,12$ & 0,29 \\
\hline Fasilitas & 0,01 & 0,93 & $-0,13$ & 0,26 \\
\hline Ketenangan & 0,36 & 0,0008 & 0,32 & 0,01 \\
\hline
\end{tabular}




\begin{tabular}{lcccc} 
Suasana Hidup & 0,20 & 0,02 & 0,34 & 0,0017 \\
\hline $\begin{array}{l}\text { Makan dan } \\
\text { Interaksi }\end{array}$ & 0,18 & 0,05 & 0,01 & 0,93 \\
\hline $\begin{array}{l}\text { Belajar dan } \\
\text { Bekerja }\end{array}$ & 0,08 & 0,32 & 0,09 & 0,37 \\
\hline Istirahat & 0,00 & 0,99 & 0,04 & 0,75 \\
\hline Hiburan & 0,24 & 0,01 & $-0,02$ & 0,86 \\
\hline R2 & 0.48 & & & 0,2 \\
$P$ & $P<.0001$ & & 0,0104 &
\end{tabular}

Perbedaan dimensi r yang
memperngaruhi $\begin{gathered}\text { kebetahan } \\ \text { dan }\end{gathered}$
kebahagiaan diperlihatkan pada tabel 6
dan diagram 1. Diagram 1 merupakan
model penyederhanan agar temuan yang
terdapat dalam tabel 6 dapat lebih mudah
dipahami. Ketenangan, suasana hidup,
dan keberadaan orang lain mempengaruhi
kebetahan ataupun kebahagiaan, tetapi
dengan besaran pengaruh (bobot regresi)
yang berbeda. Ketenangan lebih
mempengaruhi kebetahan ( $\mathrm{r}=0,36)$ daripada kebahagiaan $(r=0,32)$. Suasana hidup lebih mempengaruhi kebahagaian $(r=0,34)$ daripada kebetahan $(r=0,20)$. Keberadaan orang lain lebih berpengaruh negatif terhadap kebetahan $(r=-0,21)$ dan berpengaruh positif terhadap kebahagiaan $(r=0,23)$. Apabila mencermati pola pengaruh tiga dimensi tersebut terhadap kebetahan dan kebahagiaan, dimensi yang cenderung merepresentasikan ketiadaan orang lain dan memberikan privasi, yaitu ketenangan, lebih mempengaruhi kebetahan daripada kebahagiaan. Sebaiknya dimensi yang merepresentasikan keberadaan orang lain, yaitu suasana hidup dan keberadaan orang, cenderung meningkatkan kebahagiaan dan mengurangi kebetahan (keberadaan orang lain memiliki bobot regresi negatif).

Selain tiga dimensi di atas, pada diagram 1 dapat dilihat keberadaan dua dimensi, yaitu hiburan, serta makan dan interaksi. Dua dimensi ini hanya mempengaruhi kebetahan dan tidak mempengaruhi kebahagiaan. Hiburan memberikan kesenangan pada individu. Makan dan interaksi, juga memberikan kesenangan pada individu. Meskipun dalam kegiatan makan dan interaksi terdapat keberadaan orang, tetapi keberadaan orang tersebut merupakan keberadaan anggota keluarga, dan kegiatan makan dan interaksi diduga lebih dominan dipersepsi sebagai kegiatan yang memberikan kesenangan pada individu daripada sebagai kegiatan interaksi sosial.

Apabila melihat pola pengaruh lima dimensi terhadap kebetahan dan kebahagiaan secara bersamaan seperti dijelaskan pada dua paragraf di atas, mungkin dapat disimpulkan dimensi yang cenderung memberikan kesenangan pada seseorang secara individual lebih mempengaruhi kebetahan daripada dimensi yang memberikan kesenangan bersama dengan orang lain. Keberadaan orang lain, juga dapat memberikan kesenangan, tetapi kesenangan yang berbeda dengan kesenangan yang dinikmati saat sendirian. Keberadaan orang lain dalam durasi tertentu akan mendatangkan kebahagiaan, tetapi dalam durasi yang lama kemungkinan akan menurunkan kebetahan. Sebagai makhluk sosial, setiap orang membutuhkan keberadaan orang lain, di saat yang tepat dan dalam durasi tertentu. Interaksi sosial dengan orang lain akan mendatangkan kebahagiaan. Tetapi, jeda dari interaksi sosial, saat bagi seseorang memiliki waktu untuk mendapatkan privasi, menikmati hiburan untuk kesenangan diri sendiri juga 
diperlukan. Kebetahan dan kebahagiaan merupakan dua fenomena yang saling melengkapi. Kebetahan dibutuhkan untuk menenangkan dan kesenangan secara individual. Kebahagiaan dibutuhkan untuk kesenangan secara kolektif. Kebetahaan cenderung tidak membutuhkan keberadaan orang lain. Sebaliknya, kebahagiaan cenderung membutuhkan keberadaan orang lain.

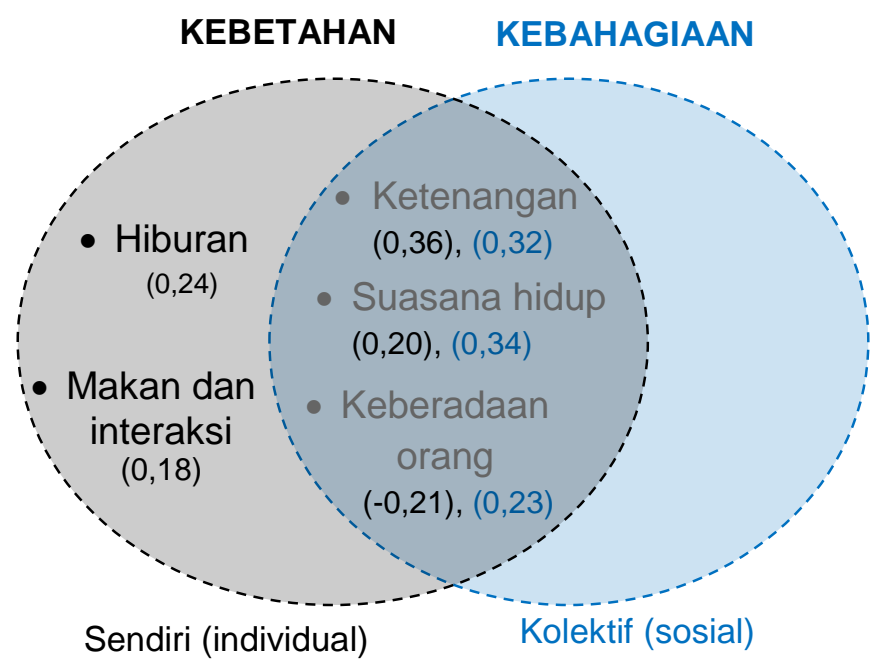

\section{Diagram 1. Perbedaan antara kebetahan dan kebahagiaan}

\section{Penutup}

\section{Kesimpulan}

Pada penelitian ini ditemukan dimensi karakteristik tempat, dimensi afektif/kognitif, dan dimensi kegiatan yang terdapat pada, dirasakan/dipikirkan, atau terjadi di ruang-ruang yang sering digunakan di dalam rumah tinggal, serta hubungan antara dimensi-dimensi tersebut dengan kebetahan dan kebahagiaan.

1. Dimensi karakteristik pada ruang yang sering digunakan di dalam rumah adalah kenyamanan, keberadaan orang, fleksibilitas, dan fasilitas. Sedangkan dimensi afektif-kognitif yang cenderung dirasakan atau dipikirkan pada ruang yang sering digunakan dalam rumah adalah ketenangan dan suasana hidup. Dimensi kegiatan yang sering dilakukan di rumah tinggal ada yang dilakukan bersama maupun yang bersifat individu yang berupa makan dan interaksi, belajar dan bekerja, istirahat dan hiburan.

2. Kebetahan berada di sebuah ruang cenderung dipengaruhi oleh ketenangan, hiburan, suasana hidup, serta makan dan interaksi. Keberadaan orang lain cenderung mengurangi kebetahan. Kebetahan terjadi apabila seseorang mendapatkan kesenangan secara individual. Kebetahan dapat terwujud apabila seseorang dapat merasa tenang, fokus, nyaman, dan rileks melakukan semua kegiatan yang diinginkannya seperti nonton televisi, bermain, berkumpul dengan keluarga, ataupun belajar dan bekerja di ruang yang secara visual, audial, dan kinestetik nyaman.

3. Kebahagiaan cenderung dipengaruhi oleh hubungan sosial, yaitu suasana hidup, ketenangan, dan keberadaan orang. Kebahagiaan akan terwujud apabila seseorang berada di ruang yang suasananya hidup bersama orang lain. 


\section{Saran}

1. Perbedaan antara kebetahan dan kebahagiaan diungkapkan pertama kali pada penelitian ini. Selain itu pengumpulan data dilakukan dengan cara non-random sampling. Karena itu, untuk meningkatkan reliabilitas, diperlukan replikasi penelitian dengan metode sampling yang berbeda.

2. Kebetahan dapat terjadi apabila seseorang mendapatkan privasi. Kebahagiaan akan didapatkan apabila terjadi interaksi sosial. Untuk mewujudkan kebetahan dan kebahagiaan dalam perencanaan dan perancangan, misalnya dapat disediakan fasilitas atau ruang yang menjaga keseimbangan antara privasi dan interaksi sosial.

\section{Ucapan Terimakasih}

Penulis mengucapkan terima kasih kepada Hanson E. Kusuma, Dr. Eng di Prodi Arsitektur, Institut Teknologi Bandung, untuk diskusi-diskusi dan pengarahannya.

\section{Daftar Pustaka}

Apriliyadi, A. (2015). PENERAPAN MODEL HIRARKI KEBUTUHAN MASLOW PADA PERILAKU KONSUMSI (Studi pada Mahasiswa Migran dari Jakarta di Universitas Brawijaya).

Ardiansyah, A. (2014). HUBUNGAN ANTARA DUKUNGAN SOSIAL TEMAN SEBAYA DENGAN KEBAHAGIAAN PADA MAHASISWA. Malang: Skripsi thesis, Universitas Islam Negeri Sultan Sarif Kasim Riau.

Atmodiwirjo, P., \& Yatmo, Y. A. (2015). Architecture as machine; Towards an architectural system for human wellbeing. Le Corbusier, 50 years later International Congress, (pp. 1-10). Valencia. doi:DOI: http://dx.doi.org/10.4995/LC2015.2015 .679
Creswell, J. W. (2012). Research Design: Qualitative, Quantitative, and Mixed Methods Approaches. Boston: Pearson Education, Inc.

Epifania, P. (2013). Menggugah Fenomena Perkembangan (?) Memaknai Rumah Saat ini: Sebuah Celoteh dari Tepian. Rumah, pp. 12-15.

Hapsari, A., \& Syahbana, J. A. (2013). Pergeseran Fungsi Rumah di Kampung Kauman Semarang. Jurnal Teknik PWK Volume 2 Nomor 1 2013, 2(1).

Impisari , I. N. (2017). Makna Kebahagiaan Pada Lansia Muslim yang Tinggal di Panti Tresna Werdha Teratai Palembang . Palembang.

Khavari. (2006). Menciptakan Kebahagiaan Dalam Setiap Keadaan. Jakarta: Serambi IImu.

Kumar, R. (2005). Research Methodology . London: SAGE Publications.

Kusyanto, M. (2016). Dimensi Ruang Keluarga Ideal. Prosiding Temu IImiah IPLBI 2016 (pp. D 023 - D 026). IPLBI.

Lawson, B. (2001). The Language of Space . Oxford: Architectural Press .

Lestari, R. (2013). KELUARGA : TEMPAT PROSES BELAJAR PERILAKU PROSOSIAL. Prosiding Seminar Nasional Parenting, (pp. 61-73).

Lewi, N., \& Sudarji, S. (2015). FAKTORFAKTOR PENDUKUNG KEBAHAGIAAN PADA EMPAT NARAPIDANA WANITA DI LAPAS WANITA KELAS II A TANGERANG. PSIBERNETIKA.

Luthfiah. (2010). Perubahan Bentuk dan Fungsi Hunian pada Rumah Susun. Ruang, 2(2).

Maslow, A. (1954). Motivation and Personality. New York: Harper and Row.

Na'imah, T., Nur'aeni, \& Septiningsih, D. S. (2017). Orientasi Happiness pada 
Orang Tua yang Memiliki Anak Tuna Grahita Ringan. Jurnal Psikologi Undip, 16(1), 32-39.

Putra, A. A., \& Nashori, F. (2008). KEBAHAGIAAN PADA PENYANDANG CACAT TUBUH. Yogyakarta: Program Studi Psikologi, Universitas Islam Indonesia.

Rachman, R. A., \& Kusuma, H. E. (2014). Definisi Kebetahan dalam Ranah Arsitektur dan Lingkungan-Perilaku. Temu IImiah IPLBI 2014 (pp. 55-60). IPLBI.

Rachman, R. A., \& Kusuma, H. E. (2016). Karakteristik Fisik-Sosial dan Kriteria Kamar yang Membuat Betah. Prosiding Temu IImiah IPLBI 2016 (pp. 53-58). Manado: IPLBI.

Veenhoven, R. (2007). Measures of Gross National Happiness. Munich Personal RePEc Archive (pp. 1-31). Rotterdam : Erasmus University Rotterdam, OECD.

Yatmo, Y. A., \& Paramita, K. D. (2013). 'RUMAH'. Rumah, pp. 6-11. 